\title{
Pastoral communications planning: perspectives and challenges
}

\author{
by Angela Ann Zukowski
}

Had I written this article a year ago, I would have a different story to tell and a different perspective to take. Now, however the economic recession and the down-sizing of dioceses is having a direct impact on the structure, administration and vision of all ministries in dioceses across the United States. Diocesan Church communication, especially, is having a difficult time surviving under the present conditions. ${ }^{1}$ This article is an attempt to reflect on our present situation. It is not a comprehensive study, but rather a basis for dialogue and reflection. The primary question before us is: „What have we learned from the past and what insights does the past offer us for the future?"

\section{The situation}

There is irony in the fact that "Aetatis Novae" has been promulgated in the midst of radical deescalation of diocesan communications across the United States. I doubt if there are many dioceses which have not been affected by cutbacks in staff, salary, services and vision. (Bishops call the down-sizing process „right-sizing" for the future.) In the past eight months I have received a minimum of ten or twelve calls a month informing me of the exploding communications crisis in the United States. This is no small issue.

Dioceses once counted on as models for supporting the design of pastoral communication plans in other dioceses are disappearing rapidly. In a few instances the discernment process regarding the consolidation of communication services/activities has involved the communication staffs, in others, they have been uninvited by-standers. Frustrated, hurt und uncertain about the

Angela Ann Zukowski, MHSH, D.Min. is the Executive Director of the Center for Religious Communications and Associate Professor in the Department of Religious Studies of the University of Dayton, Ohio, USA. She is the President of Unda-USA and First VicePresident of Unda-International.

1 There is a great sense of frustration and dissatisfaction among communicators, according to a recent survey of diocesan communicators conducted by the Catholic Communications Foundation (CCF). The general tone, stated the Most Reverend Anthony G. Bosco, chairman of CCF, was one of "voices crying out in the wilderness and hopeless dedication, if I were to categorize them“. Some of the results of the survey were:

- Annual communications budgets range from a low of $\$ 14,000$ to a high of $\$ 1,5$ million, but nearly $50 \%$ reported budgets of $\$ 100,00$ or less

- They typically reported to the Archbishop, the Bishop or the Vicar General (90\%).

- Their biggest problems, not in any particular order were:

Funding, lack of credibility with secular media, lack of support from Bishop and/or other religious, Church fear and suspicion of the media and unwillingness to treat matters with candor, lack of training and inability to deal with crisis. 
long-term impact of these emerging trends, dedicated and creative church communications personnel are beginning to look elsewhere to offer their gifts and talents. These developments are causing a drifting demise of Church communications ministry in the United States on the threshold of the $21 \mathrm{st}$ century.

While our culture rapidly progresses in the information age, speaking a new audio-visual language and communicating a new perspective on religious and cultural values, diocesan decisions regarding Church communications indicate a regression in vision. How is the church to dialogue with and transform a culture when it does not engage the media which binds the culture together? The insights of "Redemptoris Missio" speak boldly to this issue: „It is not enough to use the media simply to spread the Christian message and the Church's authentic teaching. It is also necessary to integrate the message into the ,new culture' created by modern communications ... with new languages, new techniques and a new psychology." (RM 37) Aetatis Novae encourages us to bear in mind that "today's evangelization ougth to well up from the Church's active, sympathetic presence within the world of communications." (AN 11)

Aetatis novae is a timely document. It both invites us to re-visit the wisdom and insights of "Communio et progressio" and signals the Church to pause and reconsider the opportunities communications present to the Church in the 21st century. Communications is more than one additional ministry in the Church. It is what the Church is all about. The integrity of the Church is based on how well the Church can faithfully carry out her mission in tune with the Gospel command „Go, therefore, and proclaim the Gospel to the world."

The message of Aetatis Novae is directed not only to bishops but to all persons who serve in communication, catechetical and ministry leadership positions in the church. The document reminds us that, "Catholic media work is not simply one more program alongside all the rest of the Church's activities: social communications have a role plan for communications, but Communications should be an integral part of every pastoral plan, for it has something to contribute to virtually every other apostolate, ministry and program" (AN 17). The need for an integrated pastoral plan for social communications is at the heart of Aetatis Novae. The appendix, therefore, does not stand as an after thought but as the key for implementing the vision of the document. It presents the basic steps and elements to be considered in designing an effective, integrated pastoral communications plan.

I believe there are five important challenges presented in Aetatis Novae. By reflecting on the challenges, I believe we can address the questions and concerns which face us today in diocesan communications planning. The five key challenges are: 1) equipping Church leaders to understand, interpret and speak the "new language" of the media culture (AN 1, 2, 8, 11);2) equipping all church ministers with media literacy skills (AN 4, 7, 8, 9, 12); 3) comprehending and responding to the social justice significance of the new media age and its impact on the development of peoples and cultures (AN 4, 7, 8, 9, 15); 4) equipping Church leaders and ministers with skills to use mass media and new 
technologies as a means to "offer meaningful proposals for removing obstacles to human progress and the proclamation of the Gospel" (AN 8, 11, 13, 14); and 5) designing an integrated pastoral communications plan central to all the ministries of the church (AN 21-33).

These challenges can be met if dioceses are willing to engage incollaborative efforts with all diocesan ministries to understand the meaning and role of pastoral communications for supporting the mission of the Church. This understanding is possible if Church leaders and ministers decide that quality time needs to be set aside to articulate such a rich theological understanding of communications. Aetatis Novae reminds us that such a discussion is not a luxury but a necessity for today: „As the Spirit helped the prophets of old to see the divine plan in the signs of our times and carry out its prophetic tasks, among which the study, evaluation, and right use of communications technology and the media of social communications are now fundamental". (AN 22)

As indicated in my previous comments on the current situation of Church communications in the United States, I intend to highlight some of the attempts in the United States to address the question of designing national and diocesan communication plans. In the United States, we are at a point where we need to reflect and analyze our past effort to design communication plans. What have we learned from our situation? Why did some efforts succeed and others fail? What steps do we need to take to implement the insights and vision of Aetatis Novae?

\section{Toward a national plan for Church communications}

In 1977 the United States Catholic Conference attempted to orchestrate a process to design a national plan for church communications. This effort was initiated by a variety of players. Mr. Peter Robinson, at that time President of FADICA (Foundation and Donors Intersted in Catholic Activities), expressed FADICA's concern: ,.. the Catholic foundation community in the United States need to have a better understanding of the state of the art of Catholic communications, what are critical needs, the salient issues which hopefully will form the basis for a strategic sense in terms of their own funding. “2 The individual donors of that group had been receiving requests to provide financial help for a variety of communications were used in the best possible way. Since the NCCB/USCC was contemplating implementing a national annual appeal for Church communications, FADICA members were concerned about the direction, focus and practical outcome of the appeal. The Bishops had also begun a discussion on the possibility of creating, The Catholic Telecommunications Network of America' - a satellite distribution system for the Catholic Church. This project and rapidly growing communication initiatives by both independent Catholic communicators and dioceses required a closer look for interpre-

2 A vision all can share. Toward a National Plan for Church Communications. USCC Department of Communications, New York City 1982, 1-11. 
ting the meaning and impact of these expanding communication activities.

In 1979 a FADICA-supported project which was undertaken by the USCC Department of Communications coordinated a national colloquium for select communication experts of both theory and practice. The objective was to prepare a document for national reflection in order to gather feedback for designing a national communications plan. While speaking about the goal of the project, Mr. Richard Hirsch, then Executive Secretary of the USCC Department of Communication, stated: „On the one hand, I cannot conceive of a more hazardous project than that of attempting to harnes the many entrepreneurial efforts of the Church's communications agencies - on both the national and local levels - into one unified thrust for the Church in this country.... On the other hand, it is evident that communications in this country are undergoing a cataclysmic change. ... This revolution poses substantive issues for the Church as well as for society in general, not the least of which is how the Church will use these new technologies for preaching the Gospel. Not whether, I would stress, but how"3.

The communication experts who gathered outside of Washington, D.C. in May 1979 were both religious and secular Catholic communicators representing both print and electronic communications and various ministries. For two years the committee worked on preparing the ,A Vision all can share-document. The document was sent to every diocese in the United States to be discussed with both leadership and cooperative communication agencies as a basis for collecting a critique of their collective views on Church communications. The national responses were collated, analyzed and integrated into a revised working document which was a subject of a national interdisciplinary meeting of Catholic agencies.

In 1984 the ,A vision all can share'-Conference was held at Marquette University. The conference had three separate stages: Stage One: formal presentations; Stages Two: each participant drafted recommendations for a national communication plan. A team of three group leaders combined and refined the recommendations and reported their conclusions to the working groups as the basis for stage three; Stage Three: the working groups evaluated the combined recommendations and worked on proposed amendments. These were voted on and a final writing committee refined the recordings. The finalized document was sent to all group leaders for comment and approval. The end result was that the conference created the major outlines of a vision and identified the broad tasks in which all could find their share of labor. It also identified the implications and applications for each communication effort in the Church.

It is nine years since the ,A vision all can share'-Conference. We do have a final document. But what about the desired impact? Father John Geaney, Director of the InterCommunity Telecommunications Project, argues that

3 Ebd., IV-V. 
Church communication efforts have too often focused on short term planning rather than long range strategy. „But, without a firm Church-wide strategy ... that gives the Church a plan for specific messages and intended audiences, do we know how to measure success?", he statet. ${ }^{4}$ What concrete difference did the conference have on designing a national pastoral communications plan or vision? Unfortunately, not many. It is difficult to point fingers at where and why the conference fell short of its desired goals. Perhaps as Richard Hirsch had pointed out: „This is a dangerous project ... to harness the many entrepreneurial efforts of Church communicators." Or, could it be that no one took ownership for implementing the recommendations. Where was the leadership?

I do not think the conference was a complete failure. It did bring together the national leaders of a variety of ministries in the Church to engage in dialogue on the topic. This itself is a major success. I think on the personal level there was a raising of consciousness to new ideas and insights regarding Church communications. I believe the real problem rested in the reality that the vision was impossible to realize without a sound theological understanding of communication which embraces every aspect of communication, the Church, and society. This idea, although presented at the conference, did not catch on, nor was it immediately followed up. ${ }^{5}$ In conclusion, the ,A vision all can shareBook is known by only a few of us who were engaged in the process. The turnover in Church communications personnel has been so great in the past nine years there are few left who are still more or less familiar with the document's vision.

In 1984 the Catholic Communications Campaign funded a project to produce a handbook highlighting profiles of dioceses with effective communication plans. This handbook was to give vision and direction for other dioceses to follow.

The origins of the project came from two sources. In 1981 an Unda-USA research project, funded by the Catholic Communications Campaign, turned up the rather remarkable statistic that 60 percent of diocesan communication office personnel had been in their present positions for three years or less. That remarkable fact, coupled with the fact that the USCC Department of Communication received inquires once or twice a month from diocesan communication directors regarding any communication office models that might assist them in a reorganization or creation of a local facility indicated such a handbook would be a great asset to the communication ministry of the Church.

4 Ebd., 30.

5 There have been individuals who have explored the topic of theology and communications. The Center for Religious Communications (The University of Dayton) sponsored several colloquiums which addressed the issue. In October 1992 a symposium involving ten Church Communication experts met in New York City to initiate a conversation on developing a theology of/and communications for Church ministry. 
Over 20 dioceses were visited. Each visit included an in-depth interview with diocesan communication leaders. The project outcame of the study offered encouragement and hope of support for diocesan communication efforts. In 1986 the results were published under the title "Handbook for Diocesan Communications". Much of the concern presented in the handbook dealt with the technology of communication. Although the final pages of the handbook reflected briefly on the profiles of a few dioceses, it still missed the mark of offering a practical "how-to-guide" for both bishops and diocesan communications staffs."

In 1985 the USCC Department of Communication was authorized by the NCCB to create a document on the utilization of media by the church. This document was addressed to the bishops and all communicators serving the Catholic Church. Its aim was to encourage bishops to implement fully in their local churches the communication dimension of their pastoral task. The document entitled ,In sight of all' states: „We wish to affirm the efforts begun by communicators who seek a vision of communication and church that all can share. In this reflection, we recognize the link between the church and communication, and we propose that all church communication efforts work to establish a public dialogue of fait."7 This document was an attempt to inform and capture the imagination of Church leaders to support both the national communication efforts of the Church and the design of pastoral communication plans.

Responding to the document, in 1985 the ,Center for Religious Communications' (The University of Dayton) began exploring alternative solutions for addressing the emerging needs in pastoral communications planning expressed by dioceses. A team consisting of pastoral communications and telecommunications personnel were selected to explore the telecommunication perspectives of the question. A national pilot telephone survey was conducted by Management Group Inc, in New Jersey to determine where some dioceses stood in their telecommunication efforts.

There were several results of the pilot study: 1) a conference based on the study was held at Bergamo Renewal Center to support dioceses and religious communities addressing some of their telecommunication needs and concerns $;{ }^{8}$ 2) an in-depth study of telecommunications planning in the Diocese of Greensburg, Pennsylvania was made to identify problems, concerns and solutions for a small rural dioceses in communications planning as a model for

6 I understand that a very detailed report had been prepared for the USCC Department of Communications but the cost was prohibitive to reproduce. It is for this reason the abridged form is now available. I also understand that a book was to be published on the results, it never materialized.

7 In sign of all, NCCB/USCC, washington D. C. 1986, 5.

8 The presentations are available on audio-cassettes from the Center for Religious Communications. The University of Dayton. 300 College Park, Dayton, Ohio 454690314 . 
other dioceses; 3) the production of two live-video teleconferences on Diocesan Pastoral Communications Planning (1990-1991) aired on ,The Catholic Telecommunications Network of America to all dioceses in the USA: ${ }^{10}$ 4) a national questionnaire was sent (1991) to the 179 dioceses in the USA to identify the status and profile of diocesan communications planning; and 5) a white paper is being published for reflection and dialogue on the topic with a variety of national ministry groups (1993).

\section{The status of diocesan communications planning}

Of the 179 dioceses receiving the 1991 questionnaire distributed by the ,Center for Religious Communications' in 1991, 90 were returned. The results of the study indicated:

Dioceses with a Pastoral Communications Plan

Dioceses revising or considering a Pastoral Communication Plan

Fifteen dioceses sent samples of either their diocesan communications plan or job descriptions related to their plan. ${ }^{11}$ In most situations there was an unclear understanding of how Diocesan Pastoral Communications Planning should be defined and/or what should be incorporated within it. The small dioceses indicated the size of their diocese did not warrant a detailed plan. Many dioceses indicated that the primary purpose of their communications office is to assist the bishop in communicating with the Catholic community or addressing the questions of the public media. Some of the diocesan communications directors I communicated with stated: „Even my Bishop, whom I consider one of the enlightened of the country, has a hard time in seeing a need to expand communications or even hold it to where it was two years ago." Or, „The Catholic Church's hierarchy already thinks it has a lock on communications, and that its' major way to do it is through the Sunday homily and diocesan newspaper." In speaking with a few bishops I had comments such as: „It simply does not fit into our priorities of activities at the present time." „I only see communications in light of public relations for our diocese. Anything else is superfluous unless we have the appropriate funds.“ Or, „As soon as we can wade through some of the current problems in our diocese, pastoral communications will be central to our agenda." Finally, "Our diocese is looking for persons who have a profound sense of pastoral communications planning. Where are they?" A few dioceses are beginning to go through the process of designing a diocesan pastoral com-

9 This study enabled the Diocese of Greensburg to make some major changes in their communication planning efforts.

10 Video-cassettes from these teleconferences are available from both The Catholic Telecommunications Network of America and The Center of Religious Communications (The University of Dayton).

11 Sample plans and job descripitions are to be incorporated in the White Paper being prepared for distribution in 1993. 
munications plan based on diocesan synods and/or restructuring procedures held in the late 1980 's. ${ }^{12}$

It became very obvious to us who were reviewing the survey comments that the idea of designing an integrated pastoral communications plan is a great need within the Church today. As we have spent more time in dioceses speaking with diverse diocesan ministry leaders regarding their concerns and dreams for integrating communications resources and media in their ministry, we have seen a definite need for articulating a clear vision of how communication efforts can support the local mission of the Church. In most situations, communicators, catechists, Catholic School educators, Parish Ministers and other diocesan leaders dialogue rarely with one another. Each group has its own communication needs and decision. In many situations the lack of internal communication has led to a duplication of resources and mediaexpertise at great expense to the diocese. ${ }^{13}$ That has also hindered the process for identifying a single vision of focus for collaborative ministry within the diocese. I want to note that I do not believe there is only "one" single vision for all dioceses; however, I do believe there exists a cluster of common elements as expressed in Aetatis Novae, that should be accepted by each diocese.

It is not my intention to paint a bleak scenario of diocesan communications planning in the United States. We have a number of success stories present and emerging. The challenge is attempting to monitor the developments and decisions as they impact diocesan communications across the country. The biggest challenge of all is how to communicate alternative models for assisting dioceses in addressing their communication issues and ministry needs.

We do not have space to elaborate on all the discussions we have had with diocesan personnel on their pastoral communication planning efforts. What follows, however, are a few examples of diocesan efforts to expand and strengthen their planning efforts.

In May, 1991, the Archdiocese of Louisville commissioned a study of its various communications ministries. This study, which was undertaken as part of the overall strategic plan for the Archdiocese of Louisville, evolved from an Archdiocesan Synod held a few years before. The Archdiocesan study proceeded in several stages: 1) the hiring of a consulting firm to survey through a mailed questionnaire the pulse of the local religious and civic community regarding the past and present communication efforts and image of the Catholic Church in the Louisville area; 2) the selection of a Communications Study Team made up of religious and secular com-

12 The Dioceses of Corpus Christi, Texas has been developing and revising their diocesan pastoral communication plan based on their synod mandate.

13 A good example is when the religious education office and the communications office both purchase video production equipment or operate media resource centers with no dialogue between themselves. Or, the fact that the Catholic Schools Office hires outside public relations or communication services to design a promotional package for the school when such services exist within the diocese. 
munication experts from the tri-state area to prove the perceived communication needs and concerns of both diocesan and parish personnel. The team identified a series of questions related to present communication efforts and future needs, then met with select diocesan and parish leadership groups. In June, 1991, the study team presented a series of recommendations to the Archbishop emphasizing the need for better overall direction and coordination of the various communications ministries of the Archdiocese. According to the Study Team, this overall direction and coordination of the Archdioceses's communications ministries required:

- a willingness to adapt and change the Archdiocesan approach in order to preserve the best of their traditions and to achieve their overall communications objectives in light of their recent Synod.

- better communication and collaboration among the individuals and groups who are responsible for various ministries.

- more effective and efficient use of personnel, facilities and equipment and financial resources.

In July 1991 the Archbishop appointed a chief communications officer to coordinate the work several interrelated offices. e. g. Television and Radio, Public Relations, Televising the Mass, Newspaper etc. This collaborative model promise to be more supportive of all the ministries of the local Church and more financially solvent in the future. Based on the Team's study/recommendations, the Archdiocese drafted a Vision Statement for communications which is guiding all their communication ministries. This Vision-Statement is the basis for a comprehensive communications plan which is being developed during this year as part of an extended consultation and planning process.

In speaking of the Archdiocesan plan, Mr. Daniel Conway, Chief Communications Officer, stated: „The fact that we have a vision and plan for communications that is rooted in the overall archdiocesan plan helps us to establish communications as a major funding priority. ... As long as communications is seen as a specialized ministry, and not as an integral part of everything we do as a local church, it will inevitably be regarded as something of a luxury, especially in tough economic times."

The Diocese of Greensburg, Pennsylvania, is a suburban diocese with a Catholic Population of 217,000 . Over the past 30 years, the Bishops who have led it have had a clear understanding of the importance of communications to the ministry of the diocese. As a result,this is one of the few dioceses that appears to have a well-integrated approach to pastoral communications planning. In speaking to diocesan clergy about communications, Alice Laurich, Executive Director of Diocesan Communications, stated: „But I like to think that communications is a service that enhances the important work being done by yourselves, and by my colleagues, and their staffs. It assists by creating a sense of community among the people of the diocese - and keeping all of those people whose lives you touch, informed of what is happening and how they are affected by it." 14

14 Unpublished notes from a presentation, Alice Laurich, Greensburg, Pa. 1992. 
I continue to be impressed by the reality of the Diocese of Greensburg's communication efforts. Both the print and electronic media are housed jointly, sharing not only the same resources, but having both staffs cooperate in the publishing or productions of media resources for the dioceses. The executive director is also responsible for media relations. The bishop is an active communicator himself. He not only writes a regular column in the "Catholic Accent" (Diocesan newspaper) but hosts a weekly radio and cable television programs. (The diocese also produces programming for broadcast in the Pittsburgh media market.) He encourages all members of the diocesan staff to explore how the communication efforts of the diocese can support each particular mission. This is explained periodically in workshops given by the communication office staff to other diocesan departments in which participants learn how communications can enhance their ministries. They are encouraged to use the Accent and video productions to aid in communicating their messages. Also, a parish communication handbook entitled ,Sharing the News' has been distributed to all parishes providing basic knowledge for how parishes can deal with the media. ${ }^{15}$

The new Vatican document has been a „real boost to our interdiocesan communications efforts“, states Laurich, "the document states what we really believe that ,communications is not simply one more program alongside all the rest of church activities, but that it has a role to play in every aspect of the church's mission.' That state sclearly what we have tried to do in the Diocese of Greensburg."

In the Diocese of Gaylord, Michigan, a multi-media consultant was brought into the diocese to complete a media inventory. This consultant visited with all the diocesan offices to identify their communication needs. The result was the establishment of a diocesan newspaper, a diocesan computer network, affiliation with ,The Catholic Telecommunications Network' of America, distribution of the Paulist radio programs, and the video taping of major diocesan presenters for the diocesan media resource center for parishes.

There are a number of dioceses who are either just emerging from a synod or entering into one. In dioceses where Synods have been held, I hear over and over again that communications/public relations is one of the top priorities or concerns of people in the parishes. Where I believe many of the synod statements fall short is in projecting a narrow understanding of communications verses the comprehensive view attempted in ,Aetatis Novae' und ,Communio et progressio:

\section{Challenges for the future}

Why should the church think about designing pastoral communication plans? First, studies have consistently shown that vision, planning and goal-

15 Sharing the News. Diocese of Greensburg, Pa 723 East Pittsburg Street, P.O. Box 850, Greensburg, Pa 15601. 
setting can positively infuence how an organization performs and realizes its mission. Secondly, Church leaders and ministers can become so preoccupied with day-to-day issues that they loose all sense of mission and direction. Thirdly, Pastoral Communications planning can encourage the Church to engage in future thinking, highlighting new opportunities and threats and refocussing and strengthening the mission. Fourthly, Pastoral Communications planning is a process for taking control of the so-called band-aid, short term approach in addressing the needs of the Church. Instead of running around putting out fires, so to speak, we should find ourselves planning focuses on the Church's most critical problems, choices and opportunities whithin our contemporary culture. Finally, Pastoral Communications planning is a way to resolve an interrelated set of problems or issues in an intentional, coordinated way. Faced with budget deficits, dioceses have several choices: increase revenue, cut expenses, put the diocesan structur together in a whole new way, deplete reserves, go into debt or close down communication resources and services. Pastoral Communications planning is a means for thinking through these tough choices.

There is no quick and easy way to engage in pastoral communication plannings. There are some who fell planning is so structured and controlled that it does not allow for the movement and call of the Holy Spirit. It lacks spontaneity. At the same time, however, no planning leaves the Church open to be reactive rather than proactive in her communications efforts. As I reflect on the historical attempts of the Catholic Church in the USA to design pastoral communication plans on both the national and diocesan levels, I do not find myself disillusioned. During this time of right-sizing of dioceses, I find dioceses in an opportune situation to being to clarify their theological understanding of the meaning and value of communications ministry for the mission of the Church in the 21st century. I am excited when dioceses call and ask how to begin, what models exist, what questions should be asked, and what assistance is available for them to begin the process. Their questions only confirm my determination to attempt to continue to gather the data, reflect on it's meaning, and explore alternative futures for diocesan communications planning. ${ }^{16}$

For dioceses beginning the process I recommend they spend quality time reading and reflecting on ,Communio et progressio' and "Aetatis Novae together. I have developed a simple discussion guide to assist groups through this process. In the past, Church documents on communications have had too little direct impact on the ministries within dioceses. Some people feel our communication documents lack the vision. Yet, it is our responsibility to use these documents as the basis for triggering the imagination to evoke a consciousness and perception that will serve as an alternative to the existing ideas/ images of the meaning and role of communications ministry.

16 The Center for Religious Communications (The University of Dayton), Dayton, Ohio, USA is monitoring and collating diocesan developments in pastoral communications planning as well as job descriptions and synod statements associated with the process. 
So, what kind of questions face us in the USA if our past endeavors in planning are to bear fruit? The questions are not new to many of us. The reality is we need to take quality time to reflect seriously about them in order to design our vision for Church communications in an integrated way. To begin the process, I encourage diocesan leadership/staffs as a first step to explore some of following questions:

1. What is our theology of communication? What are the elements of our theology of communication?

2. What impact does our theology of communication have on exploring alternative approaches to our communications ministry?

3. How can we implement the guidelines of ,Aetatis Novae for designing our Pastoral Communications Plan?

4. What aspects of our diocesan culture are a threat or opportunity for enabling us to realize our communication vision?

5. What are the strengths and/or weakness of our plan? Why? What can we do about it?

6. What collaborative steps need to be taken with all our diocesan ministries to enable a universal ownership of the new plan?

7. Who will be responsible for implementing, monitoring and evaluating the plan?

These questions are not exhaustive by any means. I have found, however, they do begin to establish a foundation upon which dioceses can begin to reflect on the significane of Church communications. I think Church communicators are partly at fault for the drifting demise of Church communications. Why? First, Church communicators spend a lot of time extraverting communication initiatives. While there is no doubt Church leaders are key in the support of communication plans, their posture is reactive. If Church communicators have a vision or dream, then they must work in a collaborative way with all ministries to weave their vision into the very fabric of the Catholic diocesan culture.

Secondly, many Church leaders approach communications with only short term goals (primarily based on job descriptions) or on a project by project basis, not sure what the long-range impact will be or how others can or will connect with their desired outcome for communication endeavors. Diocesan leadership must paint in broader strokes. They need a vision, for a vision an over-arching framework to guide day-to-day decisions and priorities and provides the parameters for impacting religious and public culture.

A successful vision has a tension that is the result of its having been created both from intuition (right-brain thinking) and logical analysis (left-brain thinking). It is comprehensive in both scope and sequence. Creating the vision is not an easy task.

\section{In conclusion}

I have attempted to define a number of creative initiatives by Catholic Church in the 1980's to design effective pastoral communication plan on both 
the national and diocesan level. Why did the bishops in the eighties flirt with a major commitment to telecommunications media in service to their mission, and then pull back from the challenges in as dramatic a way as they hat launched out into it in the frist place? The failure of a variety of the Church's communications enterprises in the eighties was not that our communicators did not live up to this or that set of challenges, but rather that our hierarchical leadership was, and is, unprepared to deal with the challenge American media pose for a pre-Vatican II ecclesiology. The emergence of EWTN (Eternal Word Television Network) in the 1980's and it's development, dialogue and relationship with other church communication entities and initiatives in the 1980's and 1990 's is not an insignificant point in the communications history of this era. EWTN appears to have achieved their initial vision. Perhaps the reality of EWTN indicates that entrepreneurial efforts not directly connected with the Church have a better chance of realizing their original goals. The rapid growth of VISN (Vision Inter-Faith Satellite Network) and the collaborative initiative of a number of Catholic syndicated producers indicates new approaches for using cable television for communicating our message in the 21 st century. What is the potential for EWTN, VISN and CTNA as distribution systems for the Church? Are there new opportunities for collaboration we have not tried? Will the inter or non inter-relationship of these organizations demonstrate a sense of solidarity or division for the communication endeavors of the Church? Whatever the answer they do play a role - if only a small role - in the designing of integrated pastoral communication plans for the church in the 21 st century. There are some who believe that there is nothing that our communicators could have done during the decade - that occasionally seemed so promising for church communication initiatives - which could have reversed the inevitable shutdown, the ,regression in vision" identified in this paper. Although there are many factors prevented some of these initiatives from having their full impact on Church communications in the 1990 's, I think we can learn a lot by reflecting critically on those initiatives and re-discover the vision that were present. I believe in a few instances more than the plan the process itself was of great benefit to life of the Church. The process enabled representatives from diverse ministries to come together and reflect on their common mission and explore ways to collaborate.

Diocesan Communications planning is emerging rapidly across the country. As dioceses proceed to "right-size“, dioceses are calling for synods to identify their vision and direction. In each of the synod statements I have reviewed, communications has a key role to play in the mission of the Church. Communications consultants are working closely with many dioceses to identify creative ways to integrate a richer understanding und utilization of communication resources into the very fabric of the ministry of the local Church.

There is no doubt in my mind that diocesan communication initiatives will be different in the 1990's from what they were in the late 1970's and 1980's. This is uncomfortable for individuals who have been relatively comfortable with their past and present preceptions of communications ministry. The next five to ten years will place new demands on limited diocesan resources. As stated in ,Aetatis Novae', "It naturally follows that the Church's approach to 
media and the cultural environment they help to form will differ from place to place, and that its plans and participation will be tailored to local situations." (AN 23) A structure that provides for efficiency and responsiveness; enhances cooperation, collaboration and communication; eliminates duplication; and minimizes confusion will be required to meet the challenge. The greatest challenge, therefore, that Church communicators face today is attempting to create alternative scenarios for designing integrated diocesan communication plans which enable the Church to exercise a profound dialogue of faith with contemporary culture and the community of faith.

\section{ZUSAMMENFASSUNG: Pastorale Kommunikationspläne: Perspektiven und Herausforderungen}

Es liegt Ironie in der Tatsache, daß die neue Pastoralinstruktion ,Aetatis Novae gerade zu einer Zeit erscheint, in der die diözesanen Bemühungen um kirchliche Kommunikation in den Vereinigten Staaten auf einem Tiefpunkt angelangt sind.

Die Bischöfe bezeichnen die kirchliche Abwertung diözesaner Bemühungen im Feld der Kommunikation als „richtige Neugewichtung" für die Zukunft. Trotz der Drosselung vieler Initiativen im Bereich der Kommunikation aus den 1980er Jahren gibt es jedoch einige Hoffnungsschimmer. Viele amerikanische Diözesen entwickeln z. Zt. nämlich eigene Pastoralpläne für "Kommunikation“, die z. T. mit grundlegenden Neuordnungen des kirchlichen Dienstes insgesamt einhergehen. Dabei wird das Feld der Kommunikation immer häufiger als zentrales Anliegen aller kirchlichen Aufgaben wahrgenommen und erscheint immer weniger als ein isoliertes Aufgabenfeld, das unverbunden neben anderen Aufgabenfeldern steht. Diese neuen Ansätze werden von ,Aetatis Novae' unterstützt und gefördert.

Das ,Center for Religious Communications' an der Universität Dayton (Ohio; USA) begleitet und unterstützt diese Entwicklungen. Es zeigt sich, daß viele Kirchenleitungen im Hinblick auf ,pastorale Kommunikation' oft nur an kurzfristigen Zielen oder einzelnen Projekten interessiert sind und langfristigen Bemühungen in diesem Bereich eher skeptisch gegenüberstehen. Die Verantwortlichen der Diözesen sollten aber in längeren Perspektiven denken, wie dies in einigen diözesanen Pastoralplänen bereits geschieht. Diese Planungen und Überlegungen werden auch weiterhin vom,Center for Religious Communications' dokumentiert und begleitet.

\section{RÉSUMÉ: Projets de communication pastorale: perspectives et défis}

Il y a de l'ironie dans le fait que la nouvelle instruction pastorale "Aetatis Novae" apparaisse juste au moment oú les efforts diocésains concernant la communication religieuse aux Etats-Unis en sont rendus a leur point le plus bas.

Les évêques qualifient la dévalorisation ecclésiastique des efforts diocésains dans le domaine de la communication de "nouvelle chose importante et bonne" pour l'avenir. Malgré l'étranglement de bien des initiatives dans le secteur de la communication de années quatre-vingts, il y a tout de même quelques lueurs d'espoir. Car beaucoup de diocèses américains développent actuellement leurs propres projets pastoraux pour ce qui se rapporte à la communication. Ils avancent dans l'ensemble à petits pas, mais en 
partie avec une réorganisation fondamentale du service religieux. A cette occasion, le champ de la communication est de plus en plus perçu comme une exigence centrale de toutes le missions religieuses et les missions, de moins en moins comme une tâche isolée n'ayant aucun lien avec les autres missions. Ces premiers pas sont soutenus et encouragés par "Aetatis Novae“.

Le „Centre for Religious Communications“ de l'université de Dayton (Ohio; USA) conduit et soutient ces évolutions. En ce qui concerne la communication pastorale, on voit bien que beaucoup de directions ecclésiastiques ne sont souvent intéressées que par des objectifs à court terme et qu'elles sont plutôt sceptiques face à des efforts à long terme. Les responsables des diocéses devraient penser à des perspectives à plus longue échéance comme cela est le cas dans quelques projets pastoraux diocésains. Le „Center for Religious Communications" continuera à documenter et conduire ces projets et réflexions.

\section{RESUMEN: Planos de communicación pastoral: perspectivas y desafíos}

Hay cierta ironía en el hecho de que la nueva instrucción pastoral „Aetatis Novae“ aparece justamente en un tiempo en que los esfuerzos diocesanos para lograr una comunicación eclesial en los EEUU se encuentran en un punto muy bajo.

Los obispos caracterizan la desvalorización en la iglesia de los esfuerzos diocesanos en el campo de la comunicación, como un „arreglamiento necesário“ para el futuro. A pesar del debilitamiento de muchas iniciativas en el campo de la comunicación de los años 80, existen aún algunos destellos de esperanza. Muchas diócesis norteamericanas desarrolan actualmente planos pastorales para "la comunicación", que van caminando por ahora conjuntamente con las nuevas disposiciones fundamentales del servicio eclesial. Con ello el campo de la comunicación va siendo percibido cada vez más frecuentemente como elemento central de todas las tareas de la iglesia y aparece cada vez menos como un campo aislado que se encuentra desligado de otras tareas. Esta nueva apreciación es apoyada y promovida por „Aetatis Novae".

Este desarrollo es apoyado y acompañado a su vez por el ,Centro de Comunicación Religiosa de la Universidad de Dayton' (Ohio, EEUU). Se muestra que muchas de las directrices de la iglesia en lo referente a comunicación pastoral están interesadas solamente en metas a corto plazo o en proyectos determinados, manteniendo una posición más bien escéptica frente a los esfuerzos o iniciativas a largo plazo. Los responsables de las diócesis deberían pensar, sin embargo, en perspectivas a largo plazo, como sucede ya en reflexiones continuarán siendo apoyadas por el ,Centro de Comunicación Religiosa'. 